CHAPTER 16:

\title{
The Personal, the Professional, and the Political: An Intertwined Perspective on the IEA Civic Education Studies
}

\section{Erik Amnå}

\begin{abstract}
This chapter describes a political scientist's progression from analyses of the development of Western democracies to a focused interest in young citizens' civic knowledge, attitudes, and engagement in these democracies. The IEA CIVED data are an important but not fully utilized research resource. With some notable exceptions, political scientists often seem to disregard the 18 years of preparation of first-time voters. Fueled by the Swedish parliamentary democracy commission's pleas for civic education to build the democratic infrastructure of the country, his scope of concern widened into a fascination with the political socialization taking place during adolescence in everyday life contexts. The multi-disciplinary IEA studies were a major inspiration to create a research team collaborating with developmental psychologists and communication scientists. They longitudinally followed 13 to 30-year-old Swedes over six years in order to see how political views become shaped in adulthood as alienated, passive, active, or standby citizens. More than anyone expected even a decade ago, adolescents have entered as major political actors into international, national, and local political arenas throughout the world. Political scientists have become curious about what happens in school as well as in other contexts. Furthermore, the major threats many democracies are facing in terms of climate change denial along with populism can neither be properly understood nor solved without the engagement of this generation.
\end{abstract}

\section{Introduction}

When scholars in various disciplines consider schools and wonder what they actually mean in the process of shaping young citizens and democracies in various nations, they encounter publications reporting studies from the International Association for the Evaluation of Educational Achievement (IEA), sometimes unexpectedly. This organization and its four studies in the civic education content area generously offer researchers large and unique comparative data collected with rigorously prepared instruments and analyzed along the highest scientific standards from nationally representative samples. In addition, it provides them with transparently developed theories, concepts, and instruments, and with detailed reports and archives of data that are freely available (CivicLEADS.org). More and more the IEA data have been able to satisfy the needs of researchers from fields that are much broader than the founders of the organization, who were specialists in comparative education research, would have envisioned. Yet, there is more to do in making these data and findings relevant in arguing for the civic dimension and centrality of our schools. This is especially true in the democratically troublesome time that has recently become ours. Trust is decreasing. Even a high trusting country like Sweden is witnessing a small but worrisome loss of trust among its most vulnerable groups of citizens (Rothstein and Holmberg 2020). The democratic qualities of the political system of countries such as Turkey, Russia, Venezuela, and Nicaragua appear to be weakening. In many parts of Europe populist parties are strengthening and receiving increased voter support. What do we foresee about where this process will take us? In response, where do we want to take civic education? How can this issue about a decreased support in politics and democratic principles be addressed in the future by social scientists paying closer attention to understanding the attitudes of adolescents who are

Erik Amnå, Örebro University, School of Education, Humanities and Social Sciences, Örebro, Sweden email: erik.g.amna@gmail.com

(C) IEA International Association for the Evaluation of Educational Achievement 2021 
developing political opinions that remain with them into adulthood? I am a political scientist, but this chapter will reflect on these issues from personal and professional points of view as well.

\section{Personal Perspectives}

I came to learn about the value of IEA civic education studies several years after the 1975 publication of the first study but about the time of the publication of the second in 2001. So, it was nearly two decades ago that I discovered the existence of the IEA studies and their data. It was immediately after my finalization of the report by the Swedish Governmental Commission on Democracy. The Commission aimed to be a general evaluation of the sustainability of the Swedish democracy. More than one hundred scholars from about ten disciplines were engaged in a broad review. Special attention was paid to the development of globalization including our membership in the European Union, multi-level governance, citizen participation in political parties and civil society and the political implications of emerging information technologies. A core point of departure was that "a democratic government presupposes that a civic culture of mutual respect and trust is kept alive in families, working places, pre-schools and schools, civil society and of course also in politics" (Swedish Governmental Commission on Democracy [SGCD] 2000, p. 15). One of the main threats identified by the Commission was the marginalization of youth as a result of unemployment and simultaneous retrenchments of the welfare state. It saw frightening tendencies toward growing racism and Nazism (even though the proportion of immigrants in Sweden at this time still was relatively small). In this light we argued for a dialogue between marginalized youth groups and political institutions in order to regain the political trust the latter had lost: "Furthermore, if established politicians fail to listen to these groups there will be a risk that an important opportunity for engagement will be turned into an increased marginalization; an already existing marginalization will be developed into unreachable extremism ... Youths constitute an important resource and their experiences cannot be ignored" (SGCD 2000, p. 227).

The parliamentarians of the commission unanimously argued for the centrality of the school in defending and shaping the qualities of the Swedish democracy. Its section describing the mission of citizen education said "[The school] need to foster a critical approach ... It ought to foster basic knowledge that will create conditions for individuals to value the enormous resources of knowledge in the information society and put single episodes into their contexts as well as foster critical thinking" (SGCD 2000, p. 88). It has to develop knowledge about and insights into competing societal and historical views and their consequences-and itself should remain a democratic environment allowing disagreement. What makes a democracy a democracy is not that we agree but our rights to disagree (and even that we are encouraged to disagree). The educational system is a central meeting place for different cultures and viewpoints. There we can develop a capability for dialogue and a mutual respect around the issues binding us together: "How we shall live together, how the society shall be designed, and how we shall solve conflicts without violence or threats of violence. ... However, the school's single mission may not be to teach knowledge about democracy, moral and critical thinking. It must also be a democratic arena; the students must be introduced to democracy in practice" (SGCD 2000, p. 242).

In the initial studies after the commission had launched its report, a group of post-doctoral scholars in political science together with me asked ourselves if the differences observed between the Swedish conclusions and the simultaneously ongoing democratic audits in Denmark and Norway could be traced back to attitudes, skills, and future expectations of the students in these three countries found in IEA's Civic Education Study (CIVED) (Amnå et al. 2007). At about the same time I was invited by the Swedish Parliament to make a contribution to a jubilee volume about the first 80 years of democracy in Sweden, 2008. We analyzed results from CIVED, carried out in Scandinavia in 1999, in order to predict the respondents' behavior as first-time voters in the general election of 2014. Moreover, when the election results were released in 2014 we were 
pleased to find a striking predictability from our use of the CIVED data. These two studies were realized thanks to a fruitful and decade-long cooperation with Dr Ingrid Munck, a gifted statistician who also had been deeply involved in the first generation of IEA studies of citizenship and civic education. Note that she has remained active in analyzing IEA's data with a recent publication about the scale measuring support for immigrants' rights (Munck et al. 2018).

In the next step, my personal interest in young people's civic and political engagement was further energized. When given the privilege to drive Pippa Norris, an internationally known political scientist, from Oslo Airport to a doctoral course on the Swedish North-west coast, our conversation turned to the current state of political socialization research. In particular, we shared our worries about the lagging interest that our discipline was demonstrating in an area that had shown such theoretical and methodological strength a few decades before.

After this encounter I developed the ambition to develop a Swedish longitudinal study on the civic and political development of adolescents and young adults. Since then I have been deeply involved in a professionally fascinating and demanding cooperation exploring how political socialization evolves through activities in families, peer networks, schools, social media, and associational life. At the young Örebro University, founded in 1999, I found prominent colleagues in development psychology, pedagogics, and media and communication studies whose research interests showed a promising overlap with the challenges that had occupied me ever since my work for the Commission on Democracy. Ten years after our report was presented to the government I now am able to address some of these challenges with research data. When the incoming advisory board met for the first time, one of its members, Judith Torney-Purta made sure that the new research program was informed about the vast experiences from the IEA civic education studies theoretically as well as methodologically.

\section{Professional Perspectives}

The IEA data have contributed a great deal to my research. I have been involved in various analysis, workshops, seminars, conferences, and publications utilizing IEA's civic education data. In a recent conference in collaboration with the Nordic ministers of Education, I invited scholars, teachers, school policymakers, and student representatives to approach the mission of the Nordic school in democratically troubling times. In keynote speeches and seminar presentations, IEA's International Civic and Citizenship Education Study (ICCS) 2016 played a significant role. Barbara Malak-Minkiewicz, who has been a leader in IEA's civic studies for more than 25 years, presented the Nordic students' results under the both encouraging and challenging metaphor of a lighthouse. She argued for approaching civic education as running for a target that is moving all the time while the contexts of the schools are changing over time (Carstens and Malak 2019, p. 19).

During the spring of 2019 I took part in the first Advisory Committee meeting preparing ICCS planned for 2022 (having been part of these deliberations since 2014). One of the topics I brought up for discussion is how we can bridge the traditional gap between the political scientists' focus on the interest and attitudes dimensions and the educationalists' interest in the knowledge dimensions. I will come back to this challenge later in this chapter.

My overall impression is that for too long the field of political science has unfortunately been neglecting the IEA civic education data and its findings. The first real attempt I made to wake up my colleagues was in a joint project with a junior political scientist. We were curious to compare youths from Northern and Southern Europe concerning their democratic attitudes and particularly their willingness to act politically. We aimed at matching the IEA CIVED data with data from the youngest respondents of the European Social Survey. It was a way to show how the data could illuminate vital research questions about the political and civic role of the school in democracies. We were surprised with the finding that young citizens in more established democracies seemed less activist oriented than those in the same generation living in less mature 
democracies, while their parents showed an opposite pattern. Do the adults of the South leave the ambitious orientations they perhaps had during adolescence and give up these possibilities to gain political influence? Do the seemingly passive Nordic adolescents turn into activists as adults when they start to notice problems or a need for common efforts? What was the role of the school in these two different political contexts? In addition, the unique data were also suitable for those of us interested in comparative research about young people's civic engagement and political participation (Amnå and Zetterberg 2010). At that time, I could hardly imagine that these issues would become a recurring theme in my research on standby citizens (Ekman and Amnå 2012; Amnå and Ekman 2014). When the multi-disciplinary team I coordinated at the Political Socialisation Programme at Örebro University created the code book for the five waves of that panel study, we were in many respects inspired and helped by the many years of development that had been done by the IEA civic education experts (reflected in Amnå et al. 2009; Amnå 2012). In particular, we found the ways in which they had approached the concepts of civic knowledge and of the classroom climate, highly relevant.

In general, I would argue that the limited interest in IEA's civic education studies' data generally comes from a limited interest in youth and socialization research and particularly from lack of familiarity with comparative analysis. The few exceptions like the outstanding comparative socialization studies by Marc Hooghe at Leuven (often using IEA data) clearly lead to the same conclusion (see, for example, Hooghe et al. 2016). Some of it may come from complacency on the part of educators in Sweden or an over emphasis on letting students have freedom to develop and express their own attitudes. A recent article by Reichert and Torney-Purta (2019) has highlighted the fact that a very large proportion of Swedish teachers surveyed in ICCS 2009 endorsed aims relating to fostering independent thinking; there was also somewhat more emphasis on fostering tolerance than in the other eleven countries. However, future political participation was not endorsed as an aim by substantial numbers of teachers. Moving beyond these findings to speculation, could this pattern of findings suggest unintended negative consequences? If independent thinking is by far the most important aim of Swedish teachers, does that mean they do not feel obliged to foster any value positions? Is it perhaps a problem for schools and society if students "independently" decide that they are apathetic about participation or that they want to discriminate against immigrants? Indeed, teachers' general positions and roles when dealing with attitudes toward controversial issues, including national identity, have recently been paid intensified professional and scholarly attention (Ljunggren 2014).

Currently, in 2019, I still see very few early career political science scholars using IEA data, with few exceptions (for example, Ekman and Zetterberg 2011; Arensmeier 2019). In contrast, I can see considerable curiosity among younger researchers in education, and developmental and social psychology, with whom I have had the privilege to cooperate in two large European programs: Processes Influencing Democratic Ownership and Participation (PIDOP) (BruntonSmith and Barrett 2014); and, Constructing Active Citizenship with European Youth: Policies, Practices, Challenges and Solutions (Catch-EyoU) (Serek and Jugert 2018). Perhaps the richness of IEA civic education data is clearest in multi-disciplinary research, such as the collaboration we had between educationalists and political scientists using the ICCS 2009 Swedish data. One interesting finding concerns a compositional effect. In school environments where many highly educated parents' children can be found, contexts are apparently developed that are very favorable for students' acquisition of citizen competencies. This compositional effect is particularly important for student attitudes towards immigrants, trust for institutions, political self-efficacy, civic knowledge, and participation in school democratic activities as well as for their self-prognosticated social engagement, electoral participation, and political activism. These are all positive effects after controlling for individual factors such as length of parental education and social background (Amnå et al. 2010.) 


\section{Political Perspectives}

One of my continuing questions over the years has been why there is such a discrepancy between a growing interest in IEA civic education data among scholars but ignorance on the part of politicians and policymakers. Even the civic knowledge test results regularly fail to get the politicians' attention (compared with the international rankings of students' skills in mathematics, language, and reading). The public and political discussions are increasingly shaped by the frames of reference inspired by concepts such as the global knowledge society and the information society rather than by humanistic concepts rooted in the values of sustainability, justice, solidarity, trust, and tolerance at the local or national levels. At best, democracy is being taken for granted. At worst, it is downplayed to become a subordinated dimension of students' development.

However, there has been a recent shift in this situation. Nowadays right and left extreme political parties in many countries are questioning basic democratic principles. At the same time the values of independent institutions are questioned throughout Europe. Taking all the national general elections into consideration, the populist parties are gaining support from about every fifth European voter. The social-democratic parties are gaining about the same number of voters (Timbro 2019). Even in the May 2019 European Parliamentary Election, the right-wing populist parties as well as the nationalist parties were among the victors.

So, rather suddenly not dictatorships but populism appears to constitute the major threat to our democracies. Could we have anticipated this deterioration if closer attention had been paid to the IEA citizenship and civic education data? I think so. Probably more in-depth analyses of the groups of students who neither share the democratic beliefs in rights for all nor trust the institutions of their governments might have been able to anticipate this hollowing out of the democratic values (Torney-Purta 2009; Torney-Purta and Barber 2010). Yet, we may have been too naïve when focusing on satisfaction that a considerable majority is strong defenders of vibrant liberal democracies. Like many politicians we may have been misled by the international competition among countries in knowledge scores or by the IEA methodology, which reports scale scores normed to the countries that participated (rather than scale scores that are meaningful in relating to the scale used for measurement). What might have happened if we had not chosen to ignore the fact that as many as 10-20\% of the students actually scored considerably lower than their colleagues in their understanding of and respect for core democratic principles?

We should ask ourselves whether being caught unaware of the roots among adolescents of populism, we can recover and find clues in an intense analysis of the data sets with this in mind. Therefore, I would like to outline some possible avenues for making the IEA citizenship and civic studies even more politically and educationally significant by further improving their relevance inside the classrooms as well as in the school yards and beyond. I will argue that our joint urgent civic mission is to combat the current threats and in the long run prevent a backlash against democracy by critically assessing how civic competences are developed in the light of our normative theories about civic culture. We cannot do this without understanding more deeply the role of the school in very different national and local contexts of peers, politics, media, and families (Amnå 2012).

\section{Future Perspectives}

Looking ahead, the schools' capacities to promote a civic culture as a democratic infrastructure of the democracies seems to be a key part of human development in a time of dramatic challenges. Around the world, democratic regimes are far from being "the only game in town" that many have worked for globally. On the contrary, democracies are tested and challenged, not least by many youths on both the left and right who want changes and hope for a secure and sustainable future for themselves. 
I therefore think we have to recognize that democracy is not something you have to fight for only once or until it is formally installed. Step by step we have become seriously aware how dependent its strength is on the citizens and leaders who are commissioned to design and govern its institutions. It became obvious early in the pandemic of Covid-19 in 2020 that established democracies are severely injured by their leaders' failure to lead them through various forms of crisis in ways that all parties accept as fair. In general, an increasing number of elected politicians now have the unpleasant task to compete with aggressive populist parties that are gaining widened citizen support through open denial of fundamental ethical and institutional democratic principles (Eatwell and Goodwin 2018).

The democratic dilemma is nowhere more visible than in handling the scientifically verified topic of climate change. It probably constitutes the most demanding political problem we have been forced to handle in peace time. This is because it has personal, economic, social, scientific, and political dimensions. We have to "save the earth" by mobilizing and developing some of the virtues many of the democracies now are lacking such as trust in political, scientific, and media institutions.

The youth who led huge climate demonstrations that have been taking place all over Europe seem to be in accordance with a greater voter support for the green parties in the European Parliament election of May 2019. However, European young adolescents' current initiating of school strikes in country after country are a desperate way of trying to wake up political leaders and get them to act. These citizens more than any other age group have to bear the burden of a largely ignorant adult generation. Their cry for change raises serious questions about what schools themselves are doing and could be doing confronted with their massive engagement as well as the simultaneous spread of disengagement and alienation among their school mates. From divergent points of view the engaged and the alienated seem to share some of the same deep frustration over current politics and politicians. They cannot connect current politics with satisfying answers to their urgent questions about global threats such as climate changes and migration processes. Neither do they trust politicians' willingness to listen to them. Populism is bridging these gaps by a somewhat surprising mix of denial of facts on the one hand and a merciless critique of a detached elite.

Inspired by the link between higher education and less sympathy for populism (Fitzgerald 2019) we may reflect on how our survey instruments can be further developed to deepen our understanding of both the engaged and the alienated student groups. Even if the research communities hitherto have paid far more attention to the former group, our theories are not yet fully developed to adequately understand the contrasting roots of political passivity: trust or distrust in political institutions. Concerning the alienated students we social scientists, like most of the mainstream political parties, for too long have seen their passivity as not changeable by the behavior of the political leaders or parties. We social scientists may have overlooked the dynamic and even participatory potential of these young people who are now becoming voting adults. Therefore, we had difficulties to fully understand the rapid rise of populist parties.

In the remainder of this chapter I consider three areas in need of theoretical development in order to be able to thoroughly map the nature of students' orientations to citizenship beyond the prevailing binary view of good and poor citizens.

Contested civic knowledge. Are there ways to conceptualize and measure young citizens as representing something more than negative deviations from our ideals? Can they be understood and given status as bearers of an alternative democratic ideal of deeply believing in the principle of majority rule without valuing political liberalism to balance independent institutions such as the media, courts, and the financial system? What would such an acknowledgement of a populist democratic ideal-majority rule in which the winner of the majority wins it all-imply for studies such as the IEA civic education studies? Have we misleadingly regarded only dictatorships 
(lacking both majority rule and political liberalism) to be the main threat to our democracies? The ability to understand and defend democratic ideals has to be improved but also we need critical reflection on existing democracies from various perspectives. Some of those reflections may need to be accessible for students with diverse reading capabilities (Arensmeier 2015).

Fostering tolerance represents a second area in which liberal democracy is becoming contested globally. As I touched upon above, I can see at least two general causes. Migration processes constitute a continuous challenge for our societies. The United Nations High Commissioner for Refugees has shown that in 2017 there were about 25.4 million refugees around the world. As few as 10 countries are hosting $60 \%$ of the refugees. In these countries and others with a great influx of immigrants, tensions due to diverse social habits and expressions of religious traditions and beliefs are evident.

Another tendency that may explain growing uncertainty has to do with the development of education and democracy itself. Increased socioeconomic level appears to generally be followed by changes in values that downplay loyalty, tradition, and stability while favoring self-expressing values of individuality and authenticity. This is true for social, religious, political, territorial, and sexual identities. This deep value change means an expanded room for negotiations about identities and finally an enlarged variety of differing identities. In many countries it leads to stringent challenges to tolerance towards diversity. For some countries, like the Nordic ones, it may be one of the first real tests of what is widely believed to be their world-leading high standards of tolerance. There is some evidence that males are less likely than females to practice such tolerance. All over Europe, political movements have gained great popularity among the citizens by exploiting and condemning diversity most notably by blaming the newly arrived refugees for most of the problems facing their states. More than we may have expected, schools not only can pave the way for independent thinking but have to recognize its mission to safeguard humanistic democratic principles. Teacher education needs to place more emphasis on personally encouraging and professionally arguing for upgrading their role as defenders of democracy.

Stimulating public interest in balancing the individualizing and self-actualizing forces of citizen norms in the process of common problem solving is crucial for the future development of our democracies. Political scientists continue to remind us about the powerfulness of political interest in all aspects of individuals' knowledge, attitudes, and activities in politics (Prior 2018). In this light we do not actually know much about "political" interest (Fitzgerald 2013) or about why it actually grows (Stattin et al. 2017). However, we know that people's concepts of politics correlate with gender, ideology, and nationality. We also know when this important but somewhat vague curiosity about politics develops (Prior 2018; Russo and Stattin 2017; Flanagan 2013). Political interest in particular seems to develop between the ages of 13 to 15, if it develops at all. Since we also know that political interest as well as civic knowledge correlates with (good or bad) feelings about politics, this should be recognized in classrooms. Hopes and worries regarding the climate currently seem to be a major factor explaining political interest and political participation. Emotions about politics seem to be tightly associated with political interest and civic knowledge. Furthermore, a seemingly robust disinterest can be turned into some level of political engagement though it may have a different focus from that recognized in older generations. In part, this is one thing we can learn from the seemingly rapid growth of electoral support for populist parties in European politics.

In the last analysis, civic education takes place in changing global contexts and conflicts concerning climate, economy, poverty, inequality, and politics. Moreover, the changes and conflicts require continuous open-minded reflections and experiments on the ways in which we deal with conflicts righteously and peacefully. Is there a more sustainable way to defend democracy? 


\section{References}

Amnå, E. (2012). How is civic engagement developed over time? Emerging answers from a multidisciplinary field. Journal of Adolescence, 35(3), 611-627.

Amnå, E., Ekman, T., \& Almgren, E. (2007). The end of a distinctive model of democracy? Country-diverse orientations among young adult Scandinavians. Scandinavian Political Studiesv 30(1), 61-86.

Amnå, E., Ekström, M., Kerr, M., \& Stattin, H. (2009). Political socialization and human agency: The development of civic engagement from adolescence to adulthood. Statsvetenskaplig tidskrift, 111(1), 27-40

Amnå, E., Englund, T., Arensmeier, C., Ekman, J., Ljunggren, C., Unemar Öst, I., \& Zetterberg, P. (2010). Skolor som politiska arenor: medborgarkompetens och kontrovershantering: internationella studier [Schools as political arena; citizen compentencies and dealing with controversial issues]. Stockholm, Sweden: Skolverket.

Amnå, E., \& Ekman, J. (2014). Standby citizens: diverse faces of political passivity. European Political Science Review, 6(2), 261-281.

Arensmeier, C. (2015). Swedish students' conceptual knowledge about civics and citizenship: An interview study. Citizenship Teaching \& Learning, 11(1), 9-27

Brunton-Smith, I., \& Barrett, M. (2014) Political and civic participation: findings from the modelling of existing survey data. In M. Barrett, \& B. Zani (Eds.), Political and civic engagement. Multidisciplinary perspectives (pp. 195-212). London, United Kingdom: Routledge.

Carstens, R., \& Malak, B. (2019) Comparative strengths, challenging tendencies, and future assessments. In Amnå, E. (Ed.). Nordic education in a democratically troublesome time: a conference report. Örebro, Sweden: Örebro University.

Eatwell, R., \& Goodwin, M. (2018). National populism: The revolt against liberal democracy. London, United Kingdom: Pelican Books.

Ekman, J., \& Zetterberg, P. (2011). Schools and democratic socialization: Assessing the impact of different educational settings on Swedish 14-year olds' political citizenship. Politics, Culture and Socialization, 2(2), 171-192.

Ekman, J., \& Amnå, E. (2012). Political participation and civic engagement: Towards a new typology. Human Affairs, 22(3), 283-300.

Fitzgerald, J. (2013). What does "political" mean to you? Political Behavior, 35(3), 453-479.

Fitzgerald, J. (2019). The democratic value of being in school. In E. Amnå (Ed.), Nordic education in a democratically troublesome time: a conference report. Örebro, Sweden: Örebro University.

Flanagan, C. A. (2013). Teenage citizens: The political theories of the young. Cambridge, MA: Harvard University Press.

Hooghe, M., Oser, J., \& Marien, S. (2016). A comparative analysis of 'good citizenship': A latent class analysis of adolescents' citizenship norms in 38 countries. International Political Science Review, 37(1), 115-129.

Ljunggren, C. (2014). Citizenship education and national identity: Teaching ambivalence. Policy Futures in Education, 12(1), 34-47.

Munck, I., Barber, C., \& Torney-Purta, J. (2018). Measurement invariance in comparing attitudes toward immigrants among youth across Europe in 1999 and 2009: The alignment method. Sociological Methods and Research, 47(4), 687-728. https://doi.org/10.1177/0049124117729691

Reichert, F., \& Torney-Purta, J. (2019). A cross-national comparison of teachers' beliefs about the aims of civic education in 12 countries: A person-centered analysis. Teaching and Teacher Education, 77, 112-125. Prior, M. (2018). Hooked: How politics captures people's interest. Cambridge, United Kingdom: Cambridge University Press.

Rothstein, B., \& Holmberg, S. (2020). Social Trust - The Nordic Gold? Social Europe. Research Essay No 11. https://www.socialeurope.eu/book/re-no-11-social-trust-the-nordic-gold.

Russo, S., \& Stattin, H. (2017). Stability and change in youths' political interest. Social Indicators Research, 132(2), 643-658.

Schulz, W., Ainley, J., Fraillon, J., Kerr, D., \& Losito, B. (2010). ICCS 2009 international report: Civic knowledge, attitudes and engagement among lower secondary school students in thirty-eight countries. Amsterdam, the Netherlands: International Association for the Evaluation of Educational Achievement (IEA). 
Schulz, W., Ainley, J., Fraillon, J., Losito, B., Agrusti, G., \& Friedman, T. (2018). Becoming citizens in a changing world: IEA International Civic and Citizenship Education Study 2016 international report. Cham, Switzerland: Springer. https://doi.org/10.1007/978-3-319-73963-2

Šerek, J., \& Jugert, P. (2018). Young European citizens: an individual by context perspective on adolescent European citizenship. European Journal of Developmental Psychology, 15(3), 302-323.

Stattin, H., Hussein, O., Özdemir, M., \& Russo, S. (2017). Why do some adolescents encounter everyday events that increase their civic interest whereas others do not? Developmental Psychology, 53(2), 306.

Swedish Governmental Commission on Democracy (SGCD). (2000). SOU 2000:1 En uthållig demokrati. Demokratiutredningens betänkande.[A Sustainable Democracy. The Report by the Parliamentary Commission of Democracy]. Stockholm, Sweden: Fritzes.

Timbro. (2019). The Timbro Authoritarian Populism Index. https://timbro.se/allmant/the-mostcomprehensive-index-of-populism-in-europe/

Torney-Purta, J. (2009). International psychological research that matters for policy and practice. American Psychologist, 64, 822-837.

Torney-Purta, J., \& Barber, C. (2011). Fostering young people's support for participatory human rights through their developmental niches. American Journal of Orthopsychiatry, 81, 473-481.

Torney-Purta, J., Lehmann, R., Oswald, H., \& Schulz, W. (2001). Citizenship and education in twenty-eight countries: Civic knowledge and engagement at age 14. Amsterdam, Netherlands: International Association for the Evaluation of Educational Achievement (IEA).

Torney-Purta, J., Schwille, J., \& Amadeo, J. A. (1999). Civic education across countries: Twenty-four national case studies from the IEA civic education project. Amsterdam, the Netherlands: International Association for the Evaluation of Educational Achievement (IEA).

Open Access This chapter is licensed under the terms of the Creative Commons Attribution-NonCommercial 4.0 International License (http://creativecommons.org/licenses/by-nc/4.0/), which permits any noncommercial use, sharing, adaptation, distribution and reproduction in any medium or format, as long as you give appropriate credit to the original author(s) and the source, provide a link to the Creative Commons license and indicate if changes were made.

The images or other third party material in this chapter are included in the chapter's Creative Commons license, unless indicated otherwise in a credit line to the material. If material is not included in the chapter's Creative Commons license and your intended use is not permitted by statutory regulation or exceeds the permitted use, you will need to obtain permission directly from the copyright holder. 